\title{
IMPACTS OF ELEVATED OZONE CONCENTRATION ON SOME PHYSIOLOGICAL AND MORPHOLOGICAL CHARACTERISTICS OF TWO WHEAT PLANT VARIETIES
}

\author{
BAHZAD M.T. KHALED* and EZAT Y. RAOOF ${ }^{* *}$ \\ "Dept. of Horticulture, College of Agriculture University of Duhok, Kurdistan region- Iraq \\ *Dept. of Biology, College of Science, University of Duhok, Kurdistan Region -Iraq
}

(Received: December 19, 2018; Accepted for Publication: February 23, 2019)

\begin{abstract}
Tropospheric ozone is the most important atmospheric pollutant affecting agricultural crops due to its phytotoxicity. Wheat plant, as an important and dominant cereal crop has been found to be sensitive to elevated ozone levels leading to adverse effects on growth and productivity. The objective of this study is to assess the impact of the ambient air concentration and the future increase in tropospheric ozone concentration on some physiological and morphological traits of two wheat plant (Triticum durum) varieties, Semito and Creso. Open- top chamber (OTC) field experiments were conducted during two consecutive years 2016-2017 and 2017-2018 under environmental conditions of Kurdistan region of Iraq, accumulated exposure over threshold of $40 \mathrm{ppb}$ (AOT40) was tested, the treatment were i) ambient air concentration (3237) $\mathrm{ppb}$, ii) $50 \mathrm{ppb}$ and iii) $60 \mathrm{ppb}$. Elevated Ozone concentration show a significant negative effect on total chlorophyll content (SPAD), relative water content, leaf area, plant height and consequently reducing above ground biomass, while in the same time induced increase in proline content in flag leaves. The present study demonstrate that the elevated tropospheric Ozone concentration significantly affect a range of important physiological and morphological characteristics of both varieties of wheat plant (T. durum).
\end{abstract}

KEYWORDS: Tropospheric Ozone, Triticum durum, physiological traits, morphological traits

\section{INTRODUCTION}

$\mathbf{T}$ ropospheric ozone $\left(\mathrm{O}_{3}\right)$ is recognized as one of the most effective regional and global atmospheric pollutant due to its phytotoxicity, causing threat to food security to feed the growing population across the globe (Sarkar et al, 2010). And acting as the most powerful greenhouse gases after $\mathrm{CO} 2$ and $\mathrm{CH} 4$, in opposite to stratospheric ozone which protect the earth biosphere living components from harmful ultraviolet radiation emitted from the sun (Solomon et al. 2007).

Recently it's identified as the most dominant countryside air pollutant, affecting vegetation, crops productivity and human health. As a result of huge anthropogenic emissions of $\mathrm{O} 3$ precursors e.g nitrogen oxide (NOx) and volatile organic compounds (VOC) during the last decade levels of tropospheric ozone has been increased in northern hemisphere by approximately five times from 10 $\mathrm{ppb}$ pre-industrial concentration to 50-60 ppb current concentration (Gauss et al. 2006).
Approximately $25 \%$ of earth surface is suffering from elevated ozone concentration to above $60 \mathrm{ppb}$ particularly during summer time, when high light intensity and atmospheric pressure is prevailing, and this is above the standards of accumulated exposure over a threshold of $40 \mathrm{ppb}$ (AOT40) which is crucial for injury to sensitive plant species (Monks et al., 2015).

In addition the global climate change can force more pressure on tropospheric ozone emission e.g. by modifying emissions of ozone precursors particularly biogenic volatile organic compounds (e.g. isoprene) that may be very effective to climate change in the same time (Nakicenovic and Swart, R., 2000).

In Asia mean monthly tropospheric O3 concentrations usually exceeding $50 \mathrm{ppb}$ during crops growing season ( $\mathrm{Lu}$ et al, 2010). And furthermore various simulating modeling projects indicate that globally might have more increase in ozone concentration throughout the $21^{\text {st }}$, by 20 $25 \%$ between 2015 and 2050 , and by $40-60 \%$ by 
2100, consequently more damage to agricultural crops and food production (Meehl et al., 2006, 2007).

Chronic exposure to elevated tropospheric O3 concentration it will causes a scope of negative effects on many morphological, physiological and productivity traits of plants including effects at the cellular level, visible leaf injury, reduced photosynthetic activity, accelerated senescence and consequently reducing yield (Booker et al., 2009).

Durum wheat plant (T. durum) is the second most cultivated wheat plant species in the world after the common wheat plant species (FAO, 2007). And it's also considered one of the most sensitive crops to elevated tropospheric $\mathrm{O} 3$ concentration, therefore it's estimated that the global wheat plant yield loss percentage is about $5-15 \%$ due to ambient O3 concentrations (Mauzerall\&Wang, 2001; Reitze et al 2015).

Under Mediterranean environmental conditions wheat plant is very well adapted with productivity up to 6 tons/hectare in rain-fed cultivation and its considered as a fundamental crop supporting food security and economic development for rural people (Gonzalez et al., 2013).

In northern of Iraq as a part of Mediterranean environmental conditions wheat plant is considered as the most important crop with average production up to 3.4 million tons in 20162017 (The International Grains Council (IGC) 2016).

Regardless of its importance for food security and local economic development there are no studies in best of our knowledge concerning the sensitivity of ( $T$. durum) and other agriculture crops to elevated $\mathrm{O} 3$ concentration under environmental conditions prevailing in Kurdistan region and whole Iraq,

Therefore this study will be the first one in whole Iraq to i) estimate the effects of elevated $\mathrm{O} 3$ concentration in comparison with the current ambient atmospheric concentration of tropospheric $\mathrm{O} 3$ on some physiological and morphological traits of two wheat plant cultivars; ii) to screening if different cultivars of $T$. durum show a different tolerance/sensitivity to tropospheric $\mathrm{O} 3$ in terms of growth and productivity; iii) to provide new information for improving risk assessments of the impact of tropospheric $\mathrm{O} 3$ on food security in the future, under environmental conditions of Kurdistan region.

\section{MATERIAL AND METHODS}

Field preparation and experimental design:

The experiment had been performed during the growing season of 2016-2017 and 2017-2018 for two consecutive years, at the research field of college of Agriculture, University of Duhok, Kurdistan Region at (36.86003 N, 42.869440). The experiment was planned to estimate the impact of tropospheric ozone on some qualitative and quantitative characteristics of two wheat plant varieties (T. durum Var. Semito and Var. Creso) under environmental conditions of Duhok province. The field experiment was carried out under rainfed environmental conditions. The experiment were designed as randomize complete block design (RCBD) with two factors, i.e. cultivars and Ozone concentrations with three replications. The plot size was $1 \mathrm{~m}^{2}$. Each plot was divided to five rows with $20 \mathrm{~cm}$ distance between them. The sowing rate was $30 \mathrm{~kg} / \mathrm{dunum}$ which is equal to $13 \mathrm{gm} / \mathrm{m} 2$, and the density was adjusted taking into account their actual purity and germination percentage determined according to the Omer and Ahmed (2015).Seed sowing was performed manually at November 2016 and 2017.

\section{Ozone fumigation:}

The target for elevated (O3) was (16-26 ppb approximately) above current ambient air concentrations which is about (32-37 ppb), during growing season daylight hours, based on the future prediction of tropospheric $\mathrm{O} 3$ concentration for 2050(Jagard et al, 2010).

Ozone fumigation began at anthesis growing stage when more than $50 \%$ main-stem ears flowered on April 2017 and 2018, and continued daily during daylight hours for 30 days. The maximum 3-hours average of $\mathrm{O} 3$ exposure was ambient $\mathrm{O} 3$ concentration, $50 \mathrm{ppb}$ and $60 \mathrm{ppb}$. Ozone is produced by ozone generator (QJ-002, multi -functional ozone generator, China).

Studied parameters: Many parameters concerning the physiological and morphological aspects e.g. total chlorophyll content (SPAD), relative water content (RWC), proline content, flag leaf area, plant height and total biomass, were measured during the two year of study, as explained bellow:

1- Total Chlorophyll content (SPAD) total chlorophyll was determined after about 30 days of ozone fumigation at dough development growing stage during both year of study, by taking the average of 10 flag leaves randomly for each plot 
by using chlorophyll meter SPAD - 502 (Konica Minolta Sensing, INC, made in Japan).

2- Relative water content (RWC \%) of flag leaf was measured at dough development growing stage. Were 10 fresh flag leaves taken randomly from each plot, immediately placed in plastic bag, taken to the lab and weighted fresh weight (FW) then placed in distilled water for $24 \mathrm{~h}$ for hydration under ambient room temperature (25 C) and weighted again to calculate the turgid weight (TW). Afterward the leaves were oven dried at 75 $\mathrm{C}$ for $72 \mathrm{~h}$ and the dry weight was taken. Relative water content (RWC) was calculated according to the following equation by (Muranaka et al, 2002). $\mathrm{RWC}(\%)=\underline{\mathrm{FW}-\mathrm{DW}} * 100$

$$
\text { TW }-\mathrm{DW}
$$

Where $F W$ is the fresh weight, $D W$ is the dry weight and $T W$ is turgid weight.

3- Proline content (mg/g): Proline content of the flag leaf at dough development growing stage was measured in accordance with Alaei et al (2012). Accordingly, $0.5 \mathrm{gm}$ of the fresh flag leaf was grated in $10 \mathrm{ml}$ of $0.5 \%$ aqueous toluene and shacked for 60 minute for a homogenous mixture. Then the extract was filtered by using No. 2 Wattman paper and then $2 \mathrm{ml}$ of acid ninhydrin reagent and $2 \mathrm{ml}$ of glacial acetic acid was added to the mixture. The mixture was stirred and left in water bath at $100 \mathrm{C}$ for an hour. After placing the tubes in ice water for cooling, $4 \mathrm{ml}$ of tolouene was added to the tubes. Subsequent to stirring the mixture, two distinct layers were formed after about 20 seconds. The stained upper layer was taken by a micropipette and placed in spectrophotometer at $520 \mathrm{~nm}$ and using toluene as blank.

4- Flag leaf area $(\mathbf{c m})^{2}$ was calculated at the dough development growing stage by using the following equation,

Flag leaf area $\left(\mathrm{cm}^{2}\right)=W * L * 0.75$
Where $W$ is the flag leaf width and $L$ is the flag leaf length (Kandic et al., 2009).

5- Plant height $(\mathbf{c m})$ the plant height were measured at maturity stage by taking the average of 10 plants height randomly from the earth surface to the top of the plant excluding spike length for each plot.

6- Total biomass (above ground biomass $\mathbf{K g} / \mathbf{d u n u m}$ ) air dried total biomass was determined after harvesting during June for each plot by weighting of (Straw + Grain) before threshing by using digital balance.

\section{Statistical analysis}

The data were statistically analyzed using SAS 9.4 software (SAS Institute, Inc., Cary, NC). Analysis of variance was carried out using ANOVA, and the difference between various treatments means were tested with Duncan's Multiple Range test at 5\% level. Correlation analyses were carried out in SAS 9.4 software using the CORR.

\section{Physiological traits}

\section{RESULTS}

1- Effects of elevated Ozone concentration, seasonal variation and varieties on total chlorophyll content (SPAD): The results of the effects of elevated ozone concentration, seasonal variation and varieties on total chlorophyll content of the two wheat plant varieties are presented in (Table 1). It was clear from the combinational effect $(\mathrm{S} 1+\mathrm{S} 2)$ that Semito with ambient air concentration (32-37 ppb) exhibit the highest values 56.7 in comparison to Creso with $(60 \mathrm{ppb})$ taking the lowest values 22.5. The result of elevated ozone concentration during first and second season on chlorophyll content loss was ranged between $38-53 \%$ for Semito and $39-57 \%$ for Creso.

Table (1): Effect of elevated Ozone concentrations, seasonal variation and Varieties on total chlorophyll content (SPAD) of two wheat plant varieties

\begin{tabular}{|c|c|c|c|c|c|c|}
\hline \multirow[t]{2}{*}{ Season } & \multirow[t]{2}{*}{ Varieties } & \multicolumn{3}{|c|}{ Ozone $(\mathrm{O} 3)$ concentration ppb } & \multirow[t]{2}{*}{$\checkmark$ effect } & \multirow[b]{2}{*}{ Season effect } \\
\hline & & $32-37$ & 50 & 60 & & \\
\hline \multirow[t]{3}{*}{ S1 } & Semito & 58.7 a & $35.7 \mathrm{c}$ & $28.7 \mathrm{e}$ & $41.1 \mathrm{a}$ & $39.5 \mathrm{a}$ \\
\hline & Creso & $56.3 \mathrm{~b}$ & $33.1 \mathrm{~d}$ & $24.7 \mathrm{f}$ & $38.1 \mathrm{~b}$ & \\
\hline & C effect & $57.5 \mathrm{a}$ & $34.3 \mathrm{~b}$ & $26.7 \mathrm{c}$ & & \\
\hline \multirow[t]{2}{*}{$\mathbf{S 2}$} & Semito & $54.7 \mathrm{a}$ & $33.1 \mathrm{c}$ & $23.3 \mathrm{~d}$ & $37.1 \mathrm{a}$ & $35.6 \mathrm{~b}$ \\
\hline & Creso & $50.7 \mathrm{~b}$ & $31.3 \mathrm{c}$ & $20.3 \mathrm{e}$ & $34.1 \mathrm{~b}$ & \\
\hline
\end{tabular}




\begin{tabular}{lccccc}
\hline & C effect & $52.7 \mathrm{a}$ & $32.17 \mathrm{~b}$ & $21.8 \mathrm{c}$ & \\
\hline \multirow{3}{*}{ S1 + S2 } & Semito & $56.7 \mathrm{a}$ & $34.3 \mathrm{c}$ & $26.1 \mathrm{~d}$ & $39.1 \mathrm{a}$ \\
\cline { 2 - 6 } & Creso & $53.5 \mathrm{~b}$ & $32.2 \mathrm{c}$ & $22.5 \mathrm{e}$ & $36.1 \mathrm{~b}$ \\
\cline { 2 - 6 } & & & & \\
& C effect & $55.1 \mathrm{a}$ & $33.3 \mathrm{~b}$ & $24.3 \mathrm{c}$ &
\end{tabular}

Where $\mathrm{S} 1=$ first season, $\mathrm{S} 2=$ second season, $\mathrm{S} 1+\mathrm{S} 2=$ combinational effect of season, $\mathrm{C}$ effect= concentration effect, $\mathrm{V}$ effect= varieties effect. Means following with the same letters are not significantly different according to Duncan Multiple at 0.05 levels.

2- Effects of elevated Ozone concentration, seasonal variation and varieties on relative water content (RWC \%): The results of the effects of elevated ozone concentration, seasonal variation and varieties on the relative water content of the two wheat plant varieties are presented in (Table $2)$. It was clear from the combinational effect of $(\mathrm{S} 1+\mathrm{S} 2)$ that Semito with ambient air concentration (32-37 ppb) exhibit the highest values $73.26 \%$ in comparison to Creso with (60 ppb) taking the lowest values $40.22 \%$. The result of elevated ozone concentration during first and second season on relative water content loss was ranged between $28-40 \%$ for Semito and 26-38\% for Creso.

Table (2): Effect of elevated Ozone concentrations, seasonal variation and Varieties on relative water content \% (RWC) of two wheat plant varieties

\begin{tabular}{|c|c|c|c|c|c|c|}
\hline \multirow[t]{2}{*}{ Season } & \multirow[t]{2}{*}{ Varieties } & \multicolumn{3}{|c|}{ Ozone (O3) concentration ppb } & \multirow[t]{2}{*}{$V$ effect } & \multirow[b]{2}{*}{ Season effect } \\
\hline & & $32-37$ & 50 & 60 & & \\
\hline \multirow[t]{3}{*}{ S1 } & Semito & $74.76 \mathrm{a}$ & $53.98 \mathrm{c}$ & $44.53 \mathrm{e}$ & 57.76 a & $55.43 \mathrm{a}$ \\
\hline & Creso & $66.89 \mathrm{~b}$ & $50.84 \mathrm{~d}$ & $41.56 \mathrm{f}$ & $53.11 \mathrm{~b}$ & \\
\hline & C effect & $70.83 \mathrm{a}$ & $52.41 \mathrm{~b}$ & $43.04 \mathrm{c}$ & & \\
\hline \multirow[t]{3}{*}{ S2 } & Semito & $71.76 \mathrm{a}$ & $50.98 \mathrm{c}$ & $42.53 \mathrm{~d}$ & $55.09 \mathrm{a}$ & $52.21 \mathrm{~b}$ \\
\hline & Creso & $63.89 \mathrm{~b}$ & $45.18 \mathrm{~d}$ & $38.89 \mathrm{e}$ & $49.32 \mathrm{~b}$ & \\
\hline & C effect & $67.83 \mathrm{a}$ & $48.08 \mathrm{~b}$ & $40.71 \mathrm{c}$ & & \\
\hline \multirow[t]{3}{*}{$\mathrm{S} 1$ + S2 } & Semito & $73.26 \mathrm{a}$ & $52.48 \mathrm{c}$ & $43.53 \mathrm{e}$ & $56.42 \mathrm{a}$ & \\
\hline & Creso & $65.39 \mathrm{~b}$ & $48.01 \mathrm{~d}$ & $40.22 \mathrm{f}$ & $51.21 \mathrm{~b}$ & \\
\hline & C effect & 69.33 a & $50.25 \mathrm{~b}$ & $41.88 \mathrm{c}$ & & \\
\hline
\end{tabular}

Where $\mathrm{S} 1=$ first season, $\mathrm{S} 2=$ second season, $\mathrm{S} 1+\mathrm{S} 2=$ combinational effect of season, $\mathrm{C}$ effect= concentration effect, $\mathrm{V}$ effect $=$ varieties effect. Means following with the same letters are not significantly different according to Duncan Multiple range at 0.05 levels.

3- Effects of elevated Ozone concentration, seasonal variation and varieties on proline content $(\mathrm{mg} / \mathrm{g})$ in flag leaves: The results of the effects of elevated ozone concentration, seasonal variation and varieties on the proline content of the two wheat plant varieties are presented in (Table 3). It was clear from the combinational effect of $(\mathrm{S} 1+\mathrm{S} 2)$ that Semito with ambient air concentration (32-37 ppb) exhibit the lowest values $0.80 \mathrm{mg} / \mathrm{g}$ in comparison to Creso with (60 $\mathrm{ppb})$ taking the highest values $1.50 \mathrm{mg} / \mathrm{g}$. The result of elevated ozone concentration during first and second season on proline content increase was ranged between $40-75 \mathrm{mg} / \mathrm{g}$ for Semito and 49-76 $\mathrm{mg} / \mathrm{g}$

for

Creso. 
Table (3): Effect of elevated Ozone concentrations, seasonal variation and Varieties on proline content (mg/g) of two wheat plant varieties

\begin{tabular}{|c|c|c|c|c|c|c|}
\hline Season & Varieties & $32-37$ & 50 & 60 & V effect & $\begin{array}{c}\text { Season } \\
\text { effect }\end{array}$ \\
\hline & Semito & $0.77 \mathrm{~d}$ & $1.10 \mathrm{c}$ & $1.33 \mathrm{ab}$ & $1.07 \mathrm{~b}$ & \multirow{3}{*}{$1.12 \mathrm{~b}$} \\
\hline \multirow[t]{2}{*}{ S1 } & Creso & $0.83 \mathrm{~d}$ & $1.23 \mathrm{~b}$ & $1.43 \mathrm{a}$ & $1.17 \mathrm{a}$ & \\
\hline & C effect & $0.80 \mathrm{c}$ & $1.17 b$ & $1.38 \mathrm{a}$ & & \\
\hline \multirow[t]{3}{*}{ S2 } & Creso & $0.87 \mathrm{~d}$ & $1.30 \mathrm{~b}$ & $1.57 \mathrm{a}$ & $1.24 \mathrm{a}$ & \multirow[t]{2}{*}{$1.19 \mathrm{a}$} \\
\hline & C effect & $0.85 \mathrm{c}$ & $1.22 \mathrm{~b}$ & $1.52 \mathrm{a}$ & & \\
\hline & Semito & $0.80 \mathrm{e}$ & $1.12 \mathrm{~d}$ & $1.40 \mathrm{~b}$ & $1.11 \mathrm{~b}$ & \\
\hline $\mathrm{S} 1$ + S2 & Creso & $0.85 \mathrm{e}$ & $1.27 \mathrm{c}$ & $1.50 \mathrm{a}$ & $1.21 \mathrm{a}$ & \\
\hline
\end{tabular}

Where $\mathrm{S} 1=$ first season, $\mathrm{S} 2=$ second season, $\mathrm{S} 1+\mathrm{S} 2=$ combinational effect of season, $\mathrm{C}$ effect= concentration effect, $\mathrm{V}$ effect $=$ varieties effect Means following with the same letters are not significantly different according to Duncan Multiple at 0.05 level.

\section{Morphological traits}

1 - Effects of elevated Ozone concentration, seasonal variation and varieties on flag leaf area $\left(\mathrm{cm}^{2}\right)$ : The results of the effects of elevated ozone concentration, seasonal variation and varieties on the flag leaf area of the two wheat plant varieties are presented in (Table 4). It was clear from the combinational effect of $(\mathrm{S} 1+\mathrm{S} 2)$ that Semito with ambient air concentration (32-37 ppb) exhibit the highest values $44.24 \mathrm{~cm}^{2}$ in comparison to Creso with $(60 \mathrm{ppb})$ taking the lowest values $18.87 \mathrm{~cm}^{2}$. The result of elevated ozone concentration during first and second season on leaf area loss was ranged between $38-56 \mathrm{~cm}^{2}$ for Semito and 39-52 $\mathrm{cm}^{2}$ for Creso.

Table (4): Effect of elevated Ozone concentrations, seasonal variation and Varieties on flag leaf area $\left(\mathrm{cm}^{2}\right)$ of two wheat plant varieties

\begin{tabular}{|c|c|c|c|c|c|c|}
\hline \multirow[t]{2}{*}{ Season } & \multirow[t]{2}{*}{ Varieties } & \multicolumn{3}{|c|}{ Ozone $(\mathrm{O} 3)$ concentration $\mathrm{ppb}$} & \multirow[t]{2}{*}{$\checkmark$ effect } & \multirow[b]{2}{*}{ Season effect } \\
\hline & & $32-37$ & 50 & 60 & & \\
\hline \multirow[t]{3}{*}{ S1 } & Semito & $46.41 \mathrm{a}$ & $28.57 \mathrm{c}$ & 20.17 e & $31.71 \mathrm{a}$ & $30.43 a$ \\
\hline & Creso & $43.13 \mathrm{~b}$ & $24.01 \mathrm{~d}$ & $20.37 \mathrm{e}$ & $29.19 \mathrm{~b}$ & \\
\hline & C effect & $44.77 \mathrm{a}$ & $26.29 \mathrm{~b}$ & $20.27 \mathrm{c}$ & & \\
\hline \multirow[t]{3}{*}{ S2 } & Semito & $42.08 \mathrm{a}$ & $27.91 \mathrm{c}$ & $19.17 \mathrm{e}$ & 29.72 a & $28.51 \mathrm{~b}$ \\
\hline & Creso & $39.13 \mathrm{~b}$ & $24.33 \mathrm{~d}$ & $18.37 \mathrm{e}$ & $27.28 \mathrm{~b}$ & \\
\hline & C effect & $40.61 \mathrm{a}$ & $26.12 \mathrm{~b}$ & $18.77 \mathrm{c}$ & & \\
\hline \multirow[t]{3}{*}{$\mathrm{S} 1+\mathrm{S} 2$} & Semito & $44.24 \mathrm{a}$ & $27.24 \mathrm{c}$ & $19.17 \mathrm{e}$ & $30.22 \mathrm{a}$ & \\
\hline & Creso & $40.13 \mathrm{~b}$ & $24.17 \mathrm{~d}$ & $18.87 \mathrm{e}$ & $27.72 b$ & \\
\hline & C effect & $42.68 \mathrm{a}$ & $26.20 \mathrm{~b}$ & $19.52 \mathrm{c}$ & & \\
\hline
\end{tabular}

Where $\mathrm{S} 1=$ first season, $\mathrm{S} 2=$ second season, $\mathrm{S} 1+\mathrm{S} 2=$ combinational effect of season, $\mathrm{C}$ effect= concentration effect, $\mathrm{V}$ effect $=$ varieties effect Means following with the same letters are not significantly different according to Duncan Multiple range at 0.05 level.

2 - Effects of elevated Ozone concentration, seasonal variation and varieties on plant height (cm): The results of the effects of elevated ozone concentration, seasonal variation and varieties on plant height of the two wheat plant varieties are presented in (Table 5). It was clear from the combinational effect $(\mathrm{S} 1+\mathrm{S} 2)$ that Semito with ambient air concentration (32-37 ppb) exhibit the highest values $97.81 \mathrm{~cm}$ in comparison to Creso with $(60 \mathrm{ppb})$ taking the lowest values $71.81 \mathrm{~cm}$. The result of elevated ozone concentration during first and second season on plant height loss was ranged between 12-22 cm for Semito and 7-21 cm for Creso. 
Table (5): Effect of elevated Ozone concentrations, seasonal variation and Varieties on plant height (cm) of two wheat plant varieties

\begin{tabular}{|c|c|c|c|c|c|c|}
\hline \multirow[t]{2}{*}{ Season } & \multirow[t]{2}{*}{ Varieties } & \multicolumn{3}{|c|}{ Ozone $(\mathrm{O} 3)$ concentration ppb } & \multirow[t]{2}{*}{$V$ effect } & \multirow[b]{2}{*}{ Season effect } \\
\hline & & $32-37$ & 50 & 60 & & \\
\hline \multirow[t]{2}{*}{ S1 } & Semito & $100.13 \mathrm{a}$ & $85.03 \mathrm{c}$ & $76.33 \mathrm{~d}$ & 87.17 a & 85.79 a \\
\hline & Creso & $92.91 \mathrm{~b}$ & $86.57 \mathrm{c}$ & $73.81 \mathrm{~d}$ & 84.42 b & \\
\hline \multirow[t]{3}{*}{ S2 } & Semito & $95.47 \mathrm{a}$ & 86.71 b-c & $75.33 \mathrm{~d}$ & $85.83 \mathrm{a}$ & $83.13 \mathrm{~b}$ \\
\hline & Creso & $89.23 \mathrm{~b}$ & $82.23 \mathrm{c}$ & $69.81 \mathrm{e}$ & $80.42 \mathrm{~b}$ & \\
\hline & C effect & $92.35 \mathrm{a}$ & $84.47 \mathrm{~b}$ & $72.57 \mathrm{c}$ & & \\
\hline $\mathrm{S} 1+\mathrm{S} 2$ & Semito & $97.81 \mathrm{a}$ & $85.87 \mathrm{c}$ & $75.83 \mathrm{~d}$ & $86.51 \mathrm{a}$ & \\
\hline
\end{tabular}

Where S1 = first season, S2= second season, S1+S2= combinational effect of season, $\mathrm{C}$ effect= concentration effect, $\mathrm{V}$ effect= varieties effect Means following with the same letters are not significantly different according to Duncan Multiple range at 0.05 level.

3 - Effects of elevated Ozone concentration, seasonal variation and varieties on total aboveground biomass: The results of the effects of elevated ozone concentration, seasonal variation and varieties on the total aboveground biomass of the two wheat plant varieties are presented in table (6). It was clear from the combinational effect of $(\mathrm{S} 1+\mathrm{S} 2)$ that Semito with ambient air concentration (32-37 ppb) exhibit the highest values $3714 \mathrm{~kg} /$ dunum in comparison to Creso with $(60 \mathrm{ppb})$ taking the lowest values 1911 $\mathrm{kg}$ /dunum. As a result of elevated ozone concentration during first and second season on total biomass loss was ranged between $26-41 \%$ for Semito and 22-44\% for Creso.

Table (6): Effect of elevated Ozone concentrations, seasonal variation and Varieties on total above ground biomass yield $\mathrm{Kg}$ / Dunum of two wheat plant varieties

\begin{tabular}{|c|c|c|c|c|c|c|}
\hline \multirow[t]{2}{*}{ Season } & \multirow[t]{2}{*}{ Varieties } & \multicolumn{3}{|c|}{ Ozone $(\mathrm{O} 3)$ concentration $\mathrm{ppb}$} & \multirow[t]{2}{*}{ V effect } & \multirow[b]{2}{*}{$\begin{array}{c}\text { Season } \\
\text { effect }\end{array}$} \\
\hline & & $32-37$ & 50 & 60 & & \\
\hline \multirow[t]{3}{*}{ S1 } & Semito & $3956 \mathrm{a}$ & $3050 \mathrm{c}$ & 2278 e & $3094 \mathrm{a}$ & $2965 a$ \\
\hline & Creso & $3672 b$ & $2894 \mathrm{~d}$ & $1939 \mathrm{f}$ & $2835 b$ & \\
\hline & C effect & $3814 \mathrm{a}$ & $2972 \mathrm{~b}$ & $2108 \mathrm{c}$ & & \\
\hline \multirow[t]{3}{*}{ S2 } & Semito & $3472 \mathrm{a}$ & $2439 c$ & $2061 d$ & $2657 \mathrm{a}$ & $2573 b$ \\
\hline & Creso & $3156 \mathrm{~b}$ & $2428 \mathrm{c}$ & $1883 \mathrm{e}$ & $2489 \mathrm{~b}$ & \\
\hline & C effect & $3314 \mathrm{a}$ & $2433 b$ & $1972 \mathrm{c}$ & & \\
\hline \multirow[t]{3}{*}{ S1+S2 } & Semito & $3714 \mathrm{a}$ & $2744 \mathrm{c}$ & $2169 d$ & 2876 a & \\
\hline & Creso & $3414 b$ & $2661 \mathrm{c}$ & $1911 \mathrm{~d}$ & $2662 b$ & \\
\hline & C effect & $3564 \mathrm{a}$ & $2703 \mathrm{~b}$ & $2040 \mathrm{c}$ & & \\
\hline
\end{tabular}

Where $\mathrm{S} 1=$ first season, $\mathrm{S} 2=$ second season, $\mathrm{S} 1+\mathrm{S} 2=$ combinational effect of season, $\mathrm{C}$ effect= concentration effect, $\mathrm{V}$ effect= varieties effect, Means following with the same letters are not significantly different according to Duncan Multiple range at 0.05 level.

\section{1- Total chlorophyll content (SPAD)}

In this study, elevated ozone concentration decreased total chlorophyll content (SPAD) of the flag leaves, which is act as an active assimilate source during the anthesis stage of the plant and caused accelerated senescence in both durum wheat plant cultivars (Semito and Creso). Both cultivars responded to the elevated $\mathrm{O} 3$ exposure by reducing total chlorophyll content, via an accelerated senescence and resulting in a loss in grain yield. Several studies have suggested 
chlorophyll content of flag leaves as an indicator of stress under elevated O3 concentration exposure like (Rai et al, 2008; Sarkar et al, 2010).

The elevated ozone concentration-induced decrease in total chlorophyll content suggests a generalized negative impact of the pollutant on photosynthetic pigments (Fiscus et al, 2005). In addition it is well documented that when absorbed light exceeds plant photochemical requirement in the presence of environmental restrictions, this excess energy may be transferred to the formation of reactive oxygen species ROS, which lead to destruction of photosynthetic pigments and ultimately damage chloroplast by changing membrane permeability (Demmig-Adams and Adams 2006). In a study conducted by Burkart et al (2013), they found that elevated ozone concentration severely affects photosynthetic process by influencing photosynthetic pigments (chlorophyll, carotenoids), chlorophyll fluorescence kinetics and as well as carbon fixation.

Furthermore as a result of increasing ozone concentration to $82 \mathrm{ppb}$ for 7 h day- 1 over 21 days in open top chamber OTCs with 20 wheat plant cultivars, a mean reductions in total chlorophyll content was $13 \%$ which lead to early senescence, shortening the grain filling period and result in lower grain yield (Biswas et al, 2008),

Consequently yield loss induce by elevated $\mathrm{O} 3$ concentration has often been attributed to reduction in photosynthetic activity as a results of reduction in stomatal conductance (gs) and photosynthetic pigments and the second reason is the lower supply of assimilates from the source to the sink that support reproductive development and seed growth (Fiscus et al, 2005).

\section{2- Relative water content}

The relative water content of flag leaves (relative turgidity) of a leaf is a measurement of its hydration status (actual water content) to its maximal water holding capacity at full turgidity (Avenson et al, 2005). RWC gives a strong indication of the plant's response to different environmental conditions, and its control the leaf tissue turgor pressure which ultimately maintains the activities of leaf resulting to high rate of photosynthesis (Sade et al., 2009). Increasing ozone concentration induces relative water content loss and severely limits plant physiological metabolism and growth parameters (Feng et al., 2008). Furthermore in another study conducted by Schreuder et al (2001), they observed that elevated ozone concentration to $45 \mathrm{ppb}$ during growing season increased foliar water loss and minimal conductance to water vapour of two poplar species trees. In addition plant exposure to elevated ozone concentration lead to change in leaf cuticles and accelerated wax layer erosion (Mankovska et al., 1999). And possibly leading to decreased photosynthetic gas exchange, increased pollutant deposition and increased susceptibility of foliage to infection by fungal plant pathogens (Grantz et al. , 1997).

\section{3- Proline content}

Accumulation of proline in response to adverse effects of environmental stresses like atmospheric pollution seems to be widespread among different plant species. And it's considered to be very important osmotic regulation substance in stressful environmental conditions (Chen and Murata, 2002). It has been observed that proline accumulates under stresses of water shortage, nutrient deficiency, high salinity, low temperature, heat and heavy metal exposure as a part of general adaptation to adverse environment conditions (Dencic et al, 2000; Maggio et al, 2002). In a study conducted by Zhou et al (2014), they found that elevated ozone concentration above $85 \mathrm{ppb}$ significantly increased proline content in two cultivars of winter wheat, which make the plants more resistance to oxidative damages caused by elevated ozone concentration. And this is in line with our results particularly with Semito cultivar. Furthermore wheat plant resists different stresses forms during their growth that each stress could leave various effects on the growth of the plant, metabolism and yield, based on sensitivity level and plant species growth stage (Alaei et al, 2012).

\section{4- Leaf area, plant height and total biomass:}

Recently levels of Ozone concentration in different agricultural area are known to be high enough to decrease carbon assimilation and to suppress growth and biomass accumulation in many agricultural crops and wild plant species around the world (Pleijel 2011). The adverse effects of elevated Ozone concentration on agricultural crops is highly variable depending on the cultivars, genotypic of the plant, Ozone concentration, stomatal conductance and the growth stage (Rai et al, 2010).

When Ozone enters into the plant leaves through the stomata which is exist on the underside of the leaves, it's directly react with the molecules in the cell wall that resulted in production of reactive oxygen species (ROS) 
molecules which lead to change cell wall permeability and destroying it gradually (Bhatia et al, 2012) and inhibiting photosynthesis, reducing carbon assimilation, visible leaf injury (Zhou et al., 2014), and accelerating leaf senescence, reducing plant height, plant growth and consequently reducing plant biomass (Biswas et al, 2008 ).

In a meta-analysis conducted by Pleijel et al, (2018) which is a conclusion of 33 published studies they found that non-filtered air (NF) had significant negative effects compared to charcoal filtered air (CF) on total above ground biomass $(-5.4 \%)$. In another study conducted by Tomer et al, (2015) they found that as a result of elevated Ozone concentration at flowering stage, impacted plant growth by reducing the stomatal conductance (gs) which inhibited the photosynthesis rate, reducing in carbon fixation, plant height, and leaf area and consequently leading to reduction in dry matter accumulation. Also it's observed that under elevated Ozone concentration leaf senescence is accelerated, formation of new leaves will be decreased by shortage of supply of assimilates, resulted in decreasing the number of leaves per plant, leaf area, total aboveground biomass and grain yield were decreased (Fiscus et al, 2005; wahid et al, 2006).

\section{CONCLUSSION}

The present study demonstrate that the elevated tropospheric Ozone concentration significantly affect a range of important physiological and morphological characteristics of both varieties of (T. durum var. Semito) and (T. durum var. Creso).

A significant negative relationship between elevated ozone concentrations and total chlorophyll content SPAD, relative water content, plant height, leaf area and total biomass were observed in comparison with ambient air concentration, on the other hand a significant positive relationship were observed between elevated Ozone concentration and proline content in flag leaves. The sensitivity of growth, total chlorophyll content SPAD, relative water content, plant height, leaf area, total biomass and proline content was significantly difference between the two varieties and significantly difference were observed in all variables between the two growing season.
With continuously urban sprawling, increasing petrol and other industries in the region, more atmospheric pollution by different pollutants is expected, consequently there will be need for further studies on the sensitivity of a wide range of economic crops to ambient air concentration of air pollutant like tropospheric ozone, and also place extra emphasizes on appropriate varieties selection to moderate the impact of air pollutant like tropospheric Ozone on crops production in Kurdistan Region of Iraq.

\section{REFERENCES}

- Alaei, Y., Khanghah, A. M., Jafari, M., \& Khaneghah, A. M. (2012). Evaluation on leaf proline amount in three bread wheat cultivars in presence of two fertilizers containing amino acids in drought stress. World Applied Sciences Journal, 18(9), 1190-1192.

- Avenson, T. J., Cruz, J. A., Kanazawa, A., \& Kramer, D. M. (2005). Regulating the proton budget of higher plant photosynthesis. Proceedings of the National Academy of Sciences, 102(27), 9709-9713.

- Biswas, D. K., Xu, H., Li, Y. G., Sun, J. Z., Wang, X. Z., Han, X. G., \& Jiang, G. M. (2008). Genotypic differences in leaf biochemical, physiological and growth responses to ozone in 20 winter wheat cultivars released over the past 60 years. Global Change Biology, 14(1), 46-59.

- Booker, F., Muntifering, R., McGrath, M., Burkey, K., Decoteau, D., Fiscus, E., ... \& Grantz, D. (2009). The ozone component of global change: potential effects on agricultural and horticultural plant yield, product quality and interactions with invasive species. Journal of Integrative Plant Biology, 51(4), 337-351.

- Bhatia, A., Tomer, R., Kumar, V., Singh, S. D., \& Pathak, H. (2012). Impact of tropospheric ozone on crop growth and productivity-a review.

- Burkart, S., Bender, J., Tarkotta, B., Faust, S., Castagna, A., Ranieri, A., \& Weigel, H. J. (2013). Effects of ozone on leaf senescence, photochemical efficiency and grain yield in two winter wheat cultivars. Journal of Agronomy and Crop Science, 199(4), 275-285.

- Chen, T. H., \& Murata, N. (2002). Enhancement of tolerance of abiotic stress by metabolic engineering of betaines and other compatible solutes. Current opinion in plant biology, 5(3), 250-257.

- Demmig-Adams, B., \& Adams, W. W. (2006). Photoprotection in an ecological context: the 
remarkable complexity of thermal energy dissipation. New Phytologist, 172(1), 11-21.

- Denčić, S., Kastori, R., Kobiljski, B., \& Duggan, B. (2000). Evaluation of grain yield and its components in wheat cultivars and landraces under near optimal and drought conditions. Euphytica, 113(1), 43-52.

- Feng, Z., Kobayashi, K., \& Ainsworth, E. A. (2008). Impact of elevated ozone concentration on growth, physiology, and yield of wheat (Triticum aestivum L.): a meta-analysis. Global Change Biology, 14(11), 2696-2708.

- Fiscus, E. L., Booker, F. L., \& Burkey, K. O. (2005). Crop responses to ozone: uptake, modes of action, carbon assimilation and partitioning. Plant, Cell \& Environment, 28(8), 997-1011.

- Grantz, D. A., Zhang, X. J., Massman, W. J., Delany, A., \& Pederson, J. R. (1997). Ozone deposition to a cotton (Gossypium hirsutum L.) field: stomatal and surface wetness effects during the California Ozone Deposition Experiment. Agricultural and Forest meteorology, 85(1-2), 19-31.

- González-Fernández, I., Bermejo, V., Elvira, S., De La Torre, D., González, A., Navarrete, L., ... \& Serra, J. (2013). Modelling ozone stomatal flux of wheat plant under mediterranean conditions. Atmospheric environment, 67, 149-160.

- Gauss, M., Myhre, G., Isaksen, I. S. A., Grewe, V., Pitari, G., Wild, O., ... \& Hauglustaine, D. A. (2006). Radiative forcing since preindustrial times due to ozone change in the troposphere and the lower stratosphere. Atmospheric Chemistry and Physics, 6(3), 575-599.

- Jaggard, K. W., Qi, A., \& Ober, E. S. (2010). Possible changes to arable crop yields by 2050. Philosophical Transactions of the Royal Society B: Biological Sciences, 365(1554), 2835.

- Kandić, V., Dodig, D., Jović, M., Nikolić, B., \& Prodanović, S. (2009). The importance of physiological traits in wheat breeding under irrigation and drought stress. Genetika,4l(1), 11-20.

- Lu, Z., Streets, D. G., Zhang, Q., Wang, S., Carmichael, G. R., Cheng, Y. F., ... \& Tan, Q. (2010). Sulfur dioxide emissions in China and sulfur trends in East Asia since 2000. Atmospheric Chemistry and physics, 10(13), 6311-6331.

- Mankovska, B., Percy, K. E. V. I. N., \& Karnosky, D. F. (1998). Impact of ambient tropospheric $\mathrm{O} 3, \mathrm{CO} 2$, and particulates on the epicuticular waxes of aspen clones differing in $\mathrm{O} 3$ tolerance. Ekológia (Bratislava), 18(2), 200210.

- Monks, P. S., Archibald, A. T., Colette, A., Cooper, O., Coyle, M., Derwent, R., ... \& Stevenson, D. S. (2015). Tropospheric ozone and its precursors from the urban to the global scale from air quality to short-lived climate forcer. Atmospheric Chemistry and Physics, 15(15), 8889-8973.

- Maggio, A., Miyazaki, S., Veronese, P., Fujita, T., Ibeas, J. I., Damsz, B., ... \& Bressan, R. A. (2002). Does proline accumulation play an active role in stress-induced growth reduction? The plant journal, 31(6), 699-712.

- Muranaka, S., Shimizu, K., \& Kato, M. (2002). Ionic and osmotic effects of salinity on single-leaf photosynthesis in two wheat cultivars with different drought tolerance. Photosynthetica, 40(2), 201-207.

- Mauzerall, D. L., \& Wang, X. (2001). Protecting agricultural crops from the effects of tropospheric ozone exposure: reconciling science and standard setting in the United States, Europe, and Asia. Annual Review of energy and the environment, 26(1), 237-268.

- Meehl, G. A., Washington, W. M., Santer, B. D., Collins, W. D., Arblaster, J. M., Hu, A., ... \& Strand, W. G. (2006). Climate change projections for the twenty-first century and climate change commitment in the CCSM3. Journal of climate, 19(11), 2597-2616.

- Nakicenovic, N., \& Swart, R. J. (2001). IPCC special report on emissions scenarios Cambridge University Press.

- Omer, F. A., \& Ahmed, S. (2015). Estimation of wheat seeding rate based on fixed population density and test weight by displacement. International Journal of Agricultural Policy and Research, 3(1), 39-43.

- Pleijel, H. (2011). Reduced ozone by air filtration consistently improved grain yield in wheat. Environmental pollution, 159(4), 897-902.

- Pleijel, H., Broberg, M. C., Uddling, J., \& Mills, G. (2018). Current surface ozone concentrations significantly decrease wheat plant growth, yield and quality. Science of the Total Environment, 613, 687-692.

- Rai, R., Agrawal, M., \& Agrawal, S. B. (2010). Threat to food security under current levels of ground level ozone: a case study for Indian cultivars of rice. Atmospheric Environment, 44(34), 4272-4282. 
- Reitze Jr, A. W. (2015). The National Ambient Air Quality Standards for Ozone. Ariz. J. Envtl. L. \& Pol'y, 6, 420.

- Solomon, S., Qin, D., Manning, M., Chen, Z., Marquis, M., Averyt, K. B., ... \& Miller, H. L. (2007). Climate change 2007: the physical science basis. Contribution of Working Group I to the Fourth Assessment Report of the Intergovernmental Panel on Climate Change.

- Schreuder, M. D., Van Hove, L. W., \& Brewer, C. A. (2001). Ozone exposure affects leaf wettability and tree water balance. New Phytologist, 152(3), 443-454.

- Sarkar, A., \& Agrawal, S. B. (2010). Identification of ozone stress in Indian rice through foliar injury and differential protein profile. Environmental monitoring and assessment, 161(1-4), 205-215.

- Sade, N., Vinocur, B. J., Diber, A., Shatil, A., Ronen, G., Nissan, H., ... \& Moshelion, M. (2009). Improving plant stress tolerance and yield production: is the tonoplast aquaporin SITIP2; 2 a key to isohydric to anisohydric conversion?. New Phytologist, 181(3), 651-661.

- Tomer, R., Bhatia, A., Kumar, V., Kumar, A., Singh, R., Singh, B., \& Singh, S. D. (2015). Impact of elevated ozone on growth, yield and nutritional quality of two wheat species in Northern India. Aerosol and Air Quality Research, 15(1), 329-340.

- The International Grains Council (IGC) 2016, (https://www.igc.int/downloads/publications/wg sindex.pdf).

- Wahid, A. (2006). Influence of atmospheric pollutants on agriculture in developing countries: a case study with three new wheat varieties in Pakistan. Science of the Total Environment, 371(1-3), 304-313.

- Zhou, X., Zhou, J., Wang, Y., Peng, B., Zhu, J., Yang, L., \& Wang, Y. (2015). Elevated tropospheric ozone increased grain protein and amino acid content of a hybrid rice without manipulation by planting density. Journal of the Science of Food and Agriculture, 95(1), 72-78.

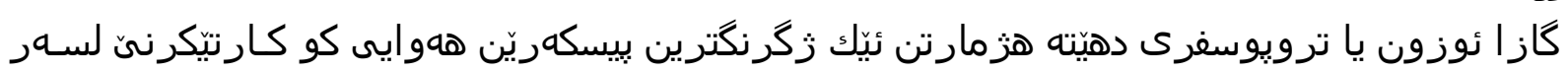

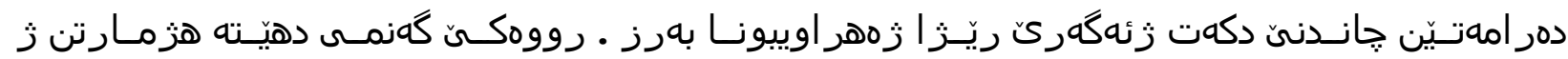

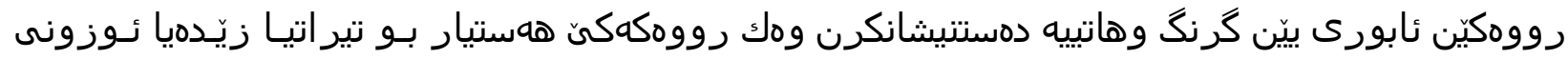

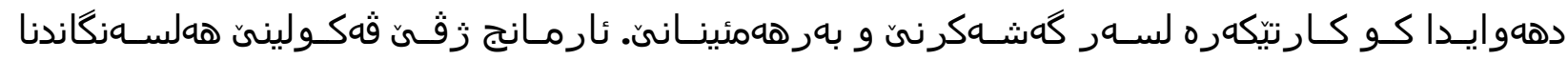

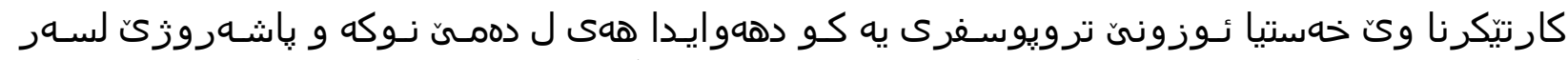

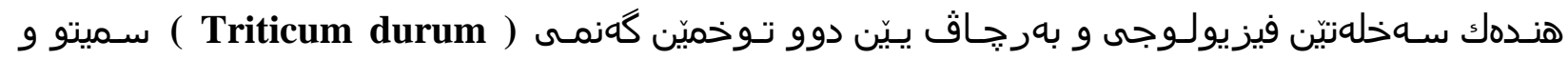

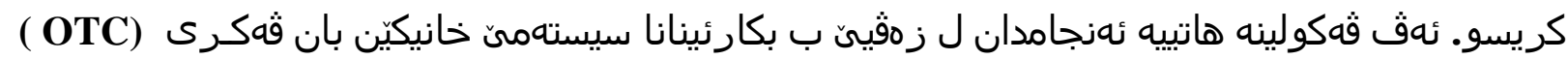

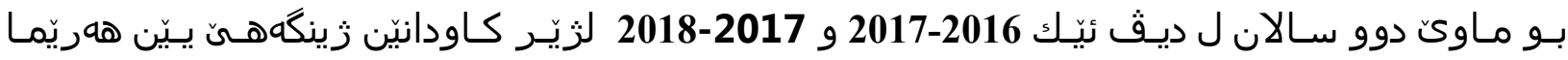

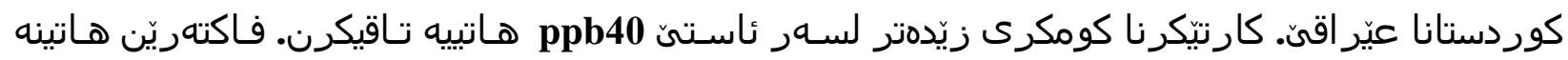

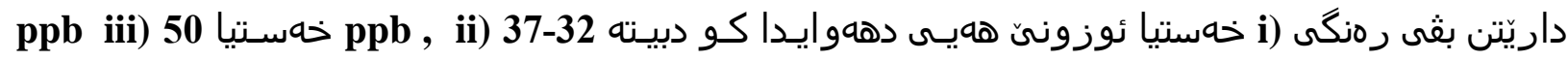

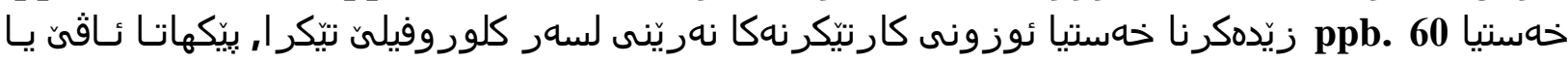

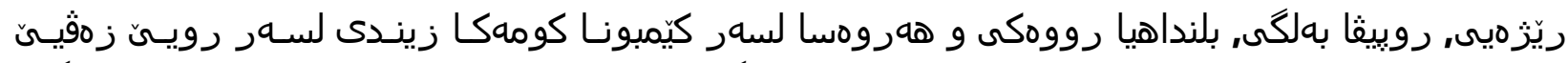

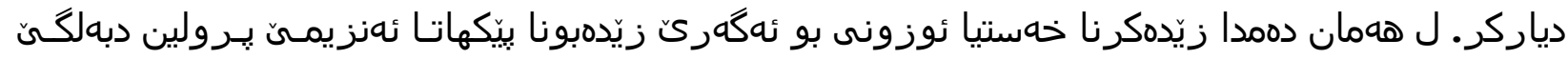

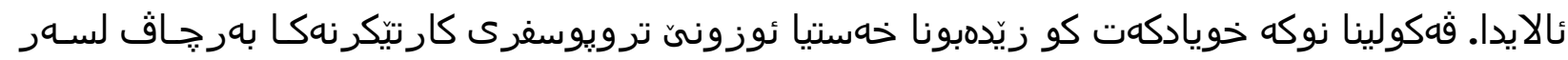

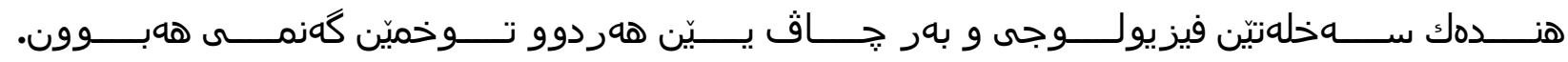




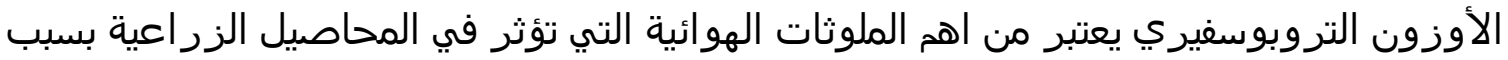

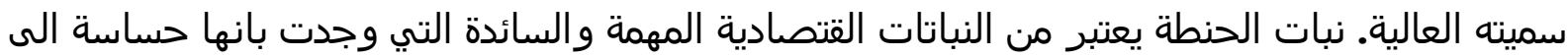

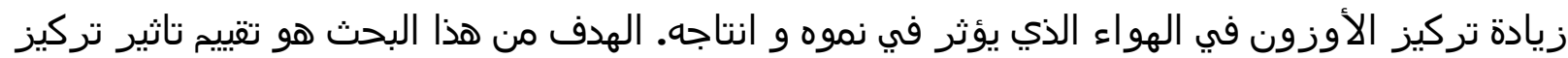

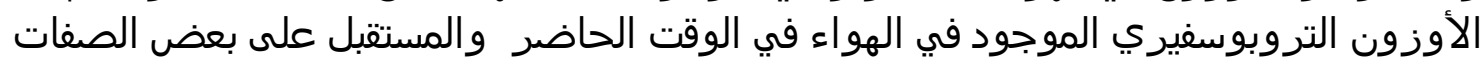

الفسيولوجية و الظاهرية لصنفين من نبات الحنطة (Triticum durum) سميتو و كريسو. تم تتفيذ هذا

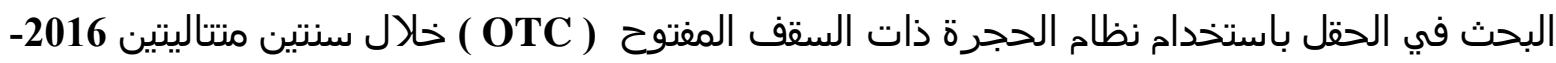

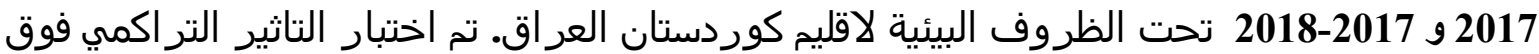

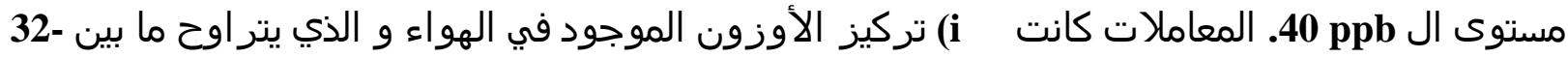

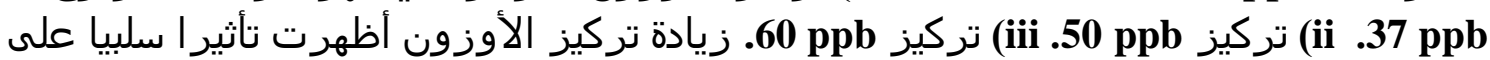

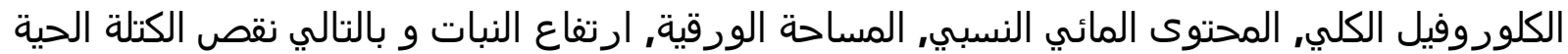

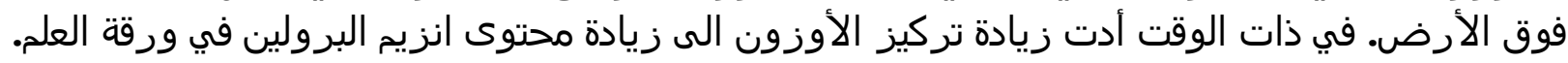

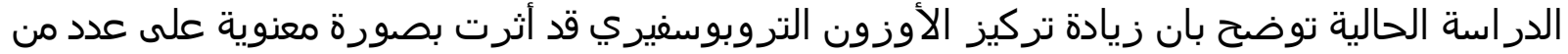

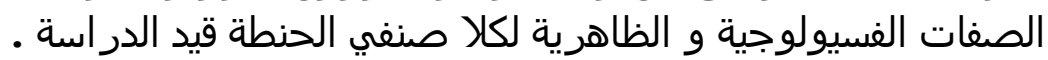

